\title{
Clinical-Epidemiological Characteristics of the First Patients Diagnosed with COVID-19 in Cuba
}

\author{
Niurka Molina-Águila MD MS, Elba Cruz-Rodríguez MD MS, Rita M. Ferrán-Torres MD MS, Belkys M. Galindo-Santana MD MS PhD, \\ Yanaris López-Almaguer MD MPH, Marcy Calderón-Martínez MD MPH, Manuel Romero-Placeres MD PhD
}

\begin{abstract}
INTRODUCTION COVID-19 is caused by the novel coronavirus SARS-CoV-2 and was declared a pandemic on March 11, 2020, the same day that the first cases in Cuba were diagnosed. In Cuba, all confirmed cases of COVID-19 were hospitalized from this point forward.
\end{abstract}

OBJECTIVE Characterize the first patients diagnosed with COVID-19 in Cuba.

METHODS We carried out a descriptive, cross-sectional study of 415 suspected cases of COVID-19 admitted to the Pedro Kourí Tropical Medicine Institute in Havana, Cuba, from March 11, 2020 through April 10, 2020. (In Cuba, all patients suspected of being COVID-19-positive were admitted to hospitals or isolation centers for observation and treatment.) Of these 415 individuals, $63(15.2 \%)$ tested positive for SARS-CoV-2. Information was obtained from the Institute's databases as well as a standardized interview form for cases confirmed or suspected as infected with the novel coronavirus. We considered the following variables: age, sex, occupation at the time of interview, national origin, personal health history, time elapsed between symptom onset and hospital admission, signs and symptoms, diagnosis and status at discharge. We based our analysis on frequency distributions and double-entry contingency tables.

RESULTS The mean age was 50 years (range: 16-94 years). The 45-54 age group represented the largest share of cases $(25.4 \%$; $16 / 63$ ); persons aged $\geq 65$ years were $20.6 \%$ (13/63); there were more men than women $(55.6 \%$ vs. $44.4 \%)$. Cubans represented $52.4 \%$ $(33 / 63)$ of patients while $47.6 \%$ (30/63) were from 14 countries where

\section{INTRODUCTION}

The current pandemic has resulted from COVID-19, an infectious respiratory disease caused by the SARS-CoV-2 virus, and is characterized by rapid spread and high fatality. $[1,2]$ Clinically, COVID-19 has been accompanied most often by fever, cough, dyspnea and pneumonic changes on chest radiography. $[3,4]$

WHO declared the novel coronavirus a pandemic on March 11, 2020 , due to its spread by that month to 58 other countries in different regions of the world, including the Americas.[1] The pandemic's evolution, in terms of incidence rates, mortality and rapid expansion, constitutes a challenge for countries' health

\section{IMPORTANCE}

We describe the main demographic and clinical-epidemiological characteristics of the first patients diagnosed with COVID-19 in Cuba, providing a reference for the history of the pandemic there.
COVID-19 had already been identified. All foreigners and Cubans who arrived from abroad were considered imported cases $(54.0 \%$; $34 / 63)$. Health personnel (10 doctors and 1 nurse) represented 17.5\% (11/63) of cases. Cough $(50.8 \%)$, fever $(46.0 \%)$, sore throat $(22.2 \%)$ and headache $(19.0 \%)$ were the most frequently reported symptoms. Asymptomatic patients represented $25.4 \%$ (16/63) of cases. Hypertension was the most frequently associated chronic disease $(28.6 \%)$, followed by asthma $(25.0 \%)$ and diabetes (17.9\%). Patients who were admitted to hospital $\geq 3$ days after symptom onset represented $66.7 \%(42 / 63)$ of cases. Mean hospital stay was 13.7 days (range: 1-27 days).

Factors associated with a higher risk of contracting the disease included occupation as a healthcare worker (OR: $1.85 ; 95 \%, \mathrm{Cl}: 0.88-3.87)$ and aged $\geq 65$ years (OR: $1.68 ; 95 \% \mathrm{Cl}: 0.85-3.34$ ).

Five individuals died, for a fatality rate of $7.9 \%$ (three foreigners and two Cubans; four men and one woman). Four of these patients were infected outside of Cuba and one was identified as a contact of a confirmed case. All patients who died had significant comorbidities (diabetes, asthma and hypertension). Age of deceased patients ranged from 54 to 87 years.

CONCLUSION The first patients diagnosed with COVID-19 in Cuba were admitted to the Pedro Kourí Tropical Medicine Institute in Havana. They share characteristics with those reported by other countries: more men than women were affected, and comorbidities including hypertension, diabetes and asthma were all important risk factors, as was age $\geq 65$ years. More than half of all cases were imported, and autochthonous patients were all contacts of confirmed cases.

KEYWORDS Pandemics, COVID-19, SARS-CoV-2, Cuba

and epidemiological surveillance systems, which must improve their capacity to detect cases and analyze the massive amounts of data generated. At the time this article was written the number of infected individuals has exceeded 88 million worldwide, with more than 1 million deaths to date in 218 countries and territories.[5-7]

COVID-19 surveillance began in Cuba in January 2020. The first cases, three Italian tourists, were confirmed at the Pedro Kouri Tropical Medicine Institute (IPK) in Havana, Cuba, on March 11, 2020. The pre-epidemic phase was declared in the country on March 27, beginning with a local transmission event in Matanzas province. During a pre-epidemic phase confirmed cases are travelers from affected countries and their local contacts. The limited autochthonous transmission phase was declared on April 7, 2020.[8] In this phase, cases in which it is not possible to establish a link with travelers from affected areas are confirmed, reported, and contact tracing is initiated.

The objective of this study is to describe the first patients admitted to IPK with suspected COVID-19, who were confirmed COVID-19-positive between March 11 and April 10,, three days 
after the limited autochthonous transmission phase was declared. This paper aims to encourage current working groups' efforts to analyze the beginning of the pandemic and provide a historical reference for studying the pandemic's evolution in Cuba.

\section{METHODS}

Study type and participants We carried out a descriptive, crosssectional study whose universe consisted of all persons suspected of having COVID-19 ( $n=415)$ who were admitted to IPK from the beginning of the pandemic on March 11, 2020-following identification of the first cases in Cuba, which occurred on the same date-until April 10, 2020. The study group consisted of 63 patients who were diagnosed as COVID-19-positive (15.2\%).

\section{Variables}

Age The sample was split into the following age groups: 15-24, 25-34, 35-44, 45-54, 55-64 and $\geq 65$ years.

Sex Male, female.

Occupation at time of COVID-19 diagnosis Employment, activity or profession.

National origin From Cuba or from abroad (including Cuban nationals living abroad).

Personal health history Coded dichotomously, the category was 'yes' if the patient had a history of respiratory disease (bronchial asthma, chronic obstructive pulmonary disease); cardiovascular disease (hypertension, ischemic heart disease); diabetes or other comorbidities referenced in the anamnesis of the patient's medical history. The category was marked as 'no' if no pre-existing conditions were mentioned.

Signs and symptoms Also coded dichotomously: 'yes' for presence of fever, cough, shortness of breath (dyspnea), headache, myalgia, arthralgia, asthenia, vomiting, diarrhea or other symptoms; and 'no' if the patient was asymptomatic at the time of admission.

Time elapsed between symptom onset and first medical visit $\leq 24$ hours, 1 day, 2 days, 3 days, 4- 6 days, $\geq 7$ days.

\section{Diagnosis}

Suspected case: if patient presented with fever, acute respiratory disease, a history of travel to countries with local COVID-19 transmission, or had contact with a confirmed case or a case under investigation up to 14 days before symptom onset. Also considered suspected cases were those who died from a severe acute respiratory infection of unknown etiology.

Confirmed case: if patient met the operational definition of a suspected case and had had SARS-CoV-2 infection confirmed by real-time polymerase chain reaction (RT-PCR) at the IPK National Reference Laboratory.

\section{Severity}

Severe: confirmed positive for SARS-CoV-2 (by RT-PCR) and presenting with acute respiratory distress syndrome, septic shock, metabolic acidosis or coagulation disorders (prognosis varied from recovery, in many cases, to torpid evolution and death).
Not severe: confirmed positive for SARS-CoV-2 (by RT-PCR), either asymptomatic or mildly symptomatic, with non-specific signs such as fever, cough, sore throat, nasal congestion, mild headache or general malaise, without signs of dehydration, dyspnea or sepsis. Patients may have presented with polypnea, with humid rales (crackles), or with atypical pneumonia, but without signs of severity and with an $\mathrm{SPO}_{2}$ (either pressure or partial oxygen saturation) of $>90 \%$. There must have been no signs of respiratory failure or severe respiratory distress.

\section{Status at discharge Alive or deceased.}

Data collection and processing All information was obtained through document review of primary sources; namely IPK's form for investigating suspected and confirmed SARS-CoV-2 cases, and IPK databases.

In order to characterize patients according to sociodemographic, clinical and epidemiological variables, the 415 cases admitted to IPK suspected of being COVID-19-positive from March 11, 2020 through April 10, 2020 were selected from the institution's database.

We constructed double-entry tables and obtained 95\% confidence intervals for odds ratios (OR) used to measure association between COVID-19 and age, sex, patient occupation and medical history.

In calculating ORs, we considered the following groups to be at increased risk of infection: people who were aged $\geq 65$ years, male sex, healthcare workers or had pre-existing comorbidities (underlying respiratory disorders, cardiovascular disease, diabetes mellitus, immunodeficiencies, cancer, kidney disease, neurological disorders, allergies, etc.).

Ethics This study was approved by the Specialized Scientific Commission on Epidemiology of the IPK Ethics Committee. Patient anonymity was guaranteed. Informed consent was deemed unnecessary as researchers only interacted with IPK database information.

\section{RESULTS}

Of the 415 suspected cases, 63 patients were confirmed to be COVID-19-positive. This was a rate from one to five cases confirmed per day, with an average of two cases per day. Male patients predominated over female at 55.6\% (35/63).

Patients' mean age was 50.6 years (range: 16-94 years), with the largest number concentrated in the $45-54$ age group $(25.4 \%$; $16 / 63)$. Patients $\geq 65$ years represented $20.6 \%$ (13/63) of the tota (Figure 1). There was one pediatric case, aged 16 years $(1.5 \%)$.

At the time of diagnosis, patient occupations included actors, construction workers, athletes, drivers, teachers, students, selfemployed, retirees and public administration employees, but the highest proportion of cases were healthcare workers in direct patient care (17.5\%; 11/63; 10 doctors and 1 nurse). Foreign travelers made up $12.7 \%(8 / 63) ; 6$ of the 8 were tourists (Figure 2 ).

Cuban citizens made up 52.4\% (33/63) of cases, and were from 7 of the country's provinces. The highest number of positives were from Havana Province (87.9\%), followed by Artemisa $(6.0 \%)$, Villa Clara (6.3\%) and Sancti Spíritus (3.2\%), and then Santiago de Cuba, 
Figure 1: Confirmed COVID-19 cases $(n=63)$ by age group, Havana, Cuba (March 11-April 10, 2020)

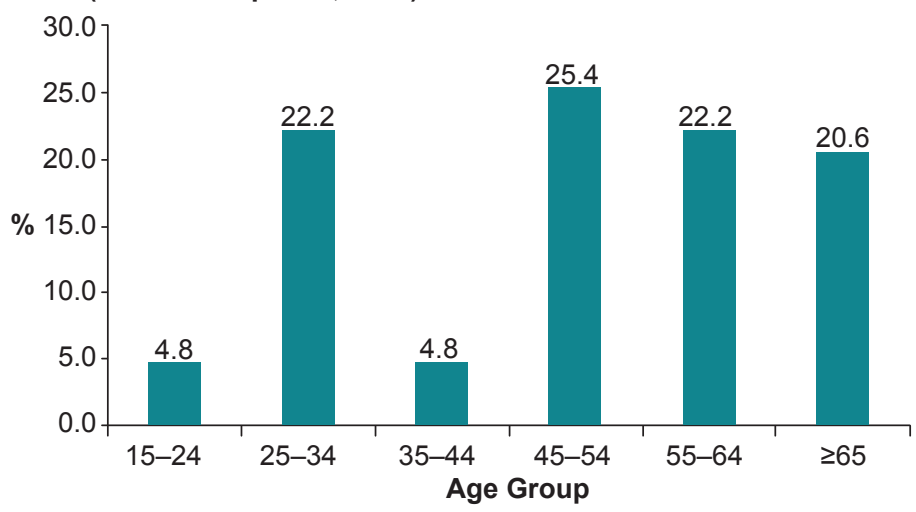

Source: COVID-19 Surveillance Database, IPK 2020

Figure 2: Confirmed COVID-19 cases $(n=63$ ), by patient employment, activity or profession at diagnosis, Havana, Cuba (March 11-April 10, 2020)

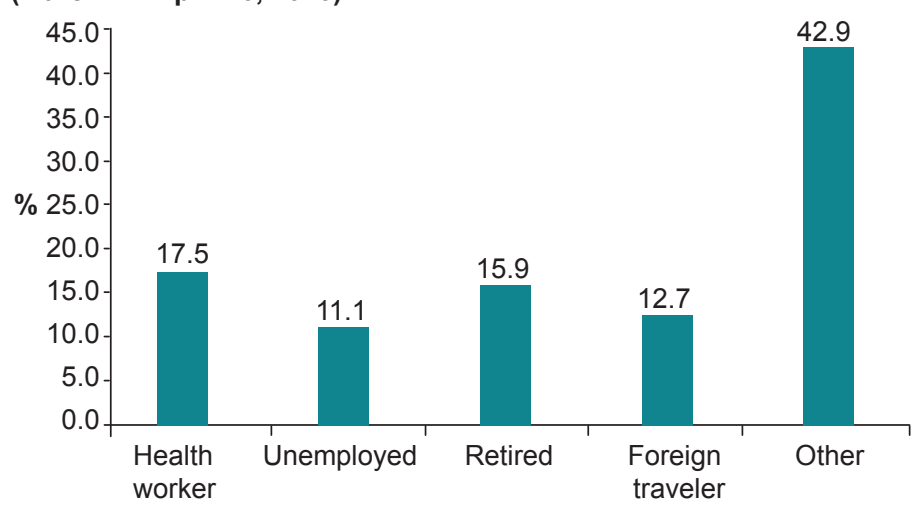

Other: driver, secretary, civil servant, actor, construction worker, self-employed, athlete, student, electrician, engineer, cook, teacher, student, government official Source: COVID-19 Surveillance Database, IPK 2020

Matanzas and Pinar del Río (at 1.6\% each). Source of infection could be identified in $100 \%$ of Cuban patients, as they either had a history of travel to countries where COVID-19 was present or had had contact with travelers (mainly from Spain, the United States, Mexico, Italy and Russia), with symptom onset that either preceded their arrival in Cuba or began $\geq 48$ hours after their arrival.

Of the 30 non-Cuban citizens, 5 were from Italy, 5 from Spain, 4 from Canada, 3 each from Russia and China, and 1 each from 10 other countries (Belgium, Bolivia, Colombia, Panama, Ecuador, France, Peru, Tanzania, United States and Mexico).

Patients traveling from abroad were admitted to IPK $<72$ hours after arrival in Cuba. Since they came from countries where the SARS-CoV-2 virus was already present, theirs were considered 'imported cases' (54.0\%; 34/63).

Pre-existing comorbidities were present in $44.4 \%(28 / 63)$ of patients; the most frequent were hypertension, asthma, diabetes mellitus and ischemic heart disease (Figure 3).

Symptoms were present in $74.6 \%$ (47/63) of patients at the time of admission; the most common were cough and fever. The remaining 25.4\% (16/63) were asymptomatic (Figure 4).
Of symptomatic patients, $53 \%(25 / 47)$ were admitted within the first 72 hours of symptom onset; $47 \%$ (22/47) were admitted later (Figure 5).

Mean hospital stay was 13.7 days (range: 1-27 days). Most patients $(92 \% ; 58 / 63)$ recovered completely and were discharged, remaining under epidemiological surveillance at the primary care level for 14 days. Two foreign travelers were evacuated to their countries of origin (Canada and the United States).

Five patients died, for an initial fatality rate of $7.9 \%$ : three nonCubans (one each from Italy, Spain and Russia) and two Cubans. Among the deceased, $80 \%$ were men aged between 54 and 87 years, all of whom had pre-existing comorbidities (diabetes mellitus, asthma and hypertension). These patients presented with a cough and a sore throat, $60 \%$ were admitted $\geq 72$ hours after symptom onset, 4 were infected outside Cuba, and 1 was a contact of a previously confirmed case.

Wide confidence intervals did not allow for conclusive inferences, but age of $\geq 65$ years, male sex, occupation in the health professions working in direct patient care, asthma and diabetes mellitus showed striking correlations with COVID-19-positivity (Table 1).

Figure 3: Confirmed COVID-19 cases $(n=63)$ by associated comorbidities, Havana, Cuba (March 11-April 10, 2020)

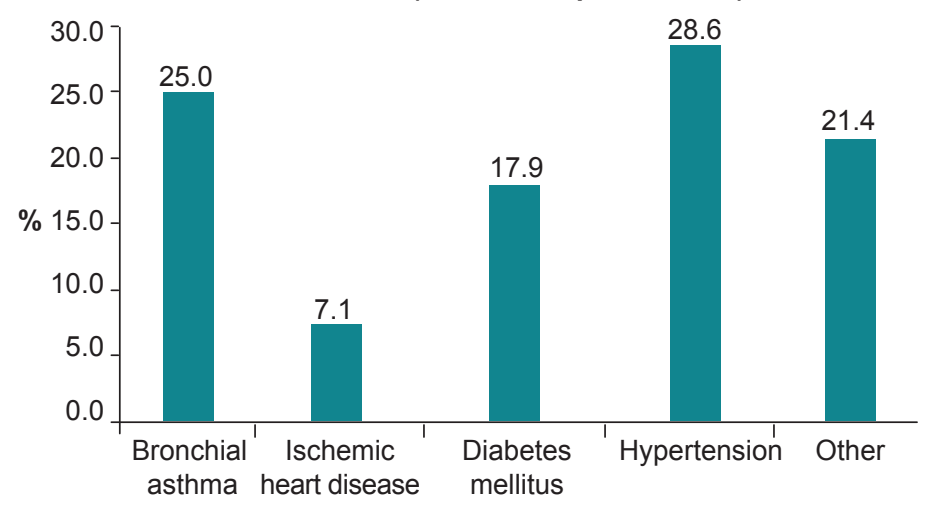

Other: HIV, cancers, epilepsy, arthritis, hypothyroidism, kidney disease, etc. Source: COVID-19 Surveillance Database, IPK 2020

Figure 4: Confirmed COVID-19 cases $(n=63)$ by signs and symptoms, Havana, Cuba (March 11-April 10, 2020)

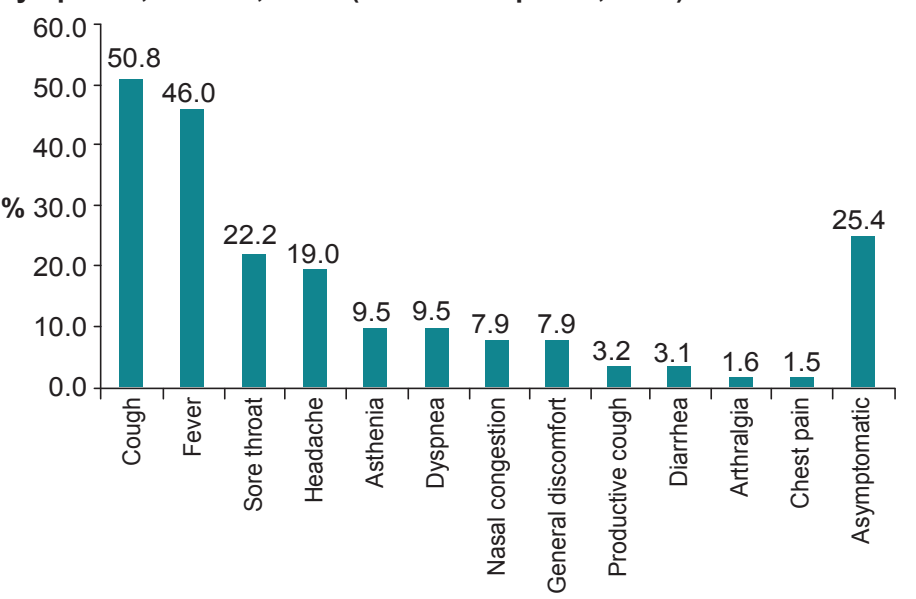

Source: COVID-19 Surveillance Database, IPK 2020 
Figure 5: Confirmed COVID-19 cases $(n=63)$ by time elapsed between symptom onset and hospital admission, Havana, Cuba (March 11-April 10, 2020)

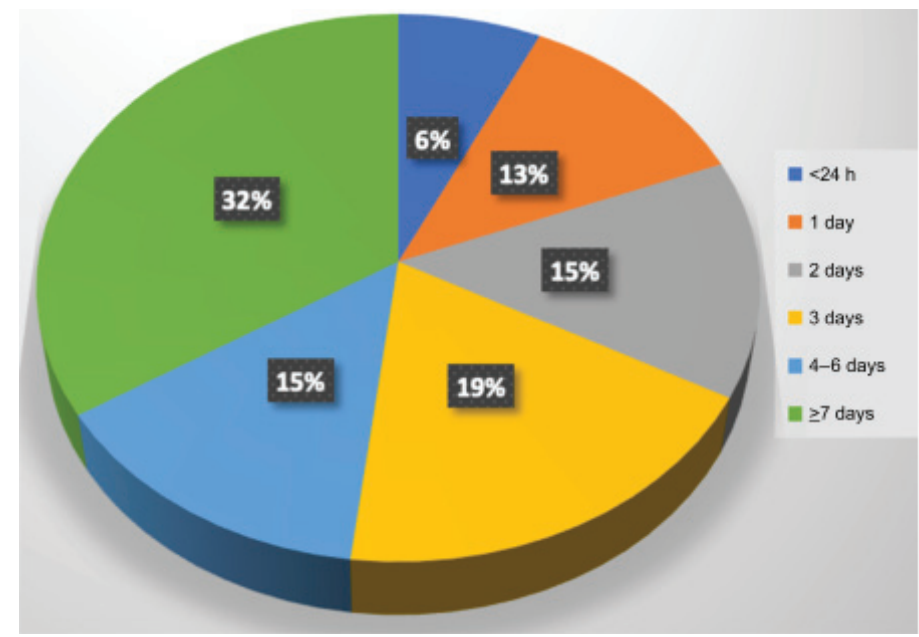

Source: COVID-19 Surveillance Database, IPK 2020

\section{DISCUSSION}

Results for sex and age variables showed similarities with other studies of confirmed COVID-19 cases. Male sex was slightly more frequent in this study, in agreement with other studies of COVID-19 conducted in Cuba.[10,11] In a press report by Carmona and Fariñas, men accounted for $50.7 \%$ of the 564 cases confirmed by the end of the first month of the epidemic in Cuba.[12] However, the Carmona-Fariñas press report showed that $13.9 \%$ of those affected were children,[12] while the IPK sample of 415 cases had only one pediatric patient (a 16-year old).

Age distributions have been variable, with a general trend of fewer cases among those $<45$ years of age, as was observed in our study, and more cases occurring in those $\geq 45$ years. $\mathrm{Li}$ found a similar result in Wuhan, China, in the first 425 confirmed COVID-19 cases; a median age of 59 years, $56 \%$ male, and no initial cases $<15$ years of age.[13] Sun found an average age of 46 years, $55 \%$ male, and $3 \%<15$ years old in the first 507 cases confirmed in China between January 13 and January 31, 2020. [14] The WHO mission in China examined 55,924 confirmed COVID-19 cases, finding $51 \%$ male, with a median age of 51 years and cases concentrated in the age range of 30-69 years. [15] A report by Spain's National Epidemiology Center examining

Table 1: Demographic and clinical variables for patients confirmed and suspected of COVID-19, Havana, Cuba (March 11-April 10, 2020)

\begin{tabular}{|c|c|c|c|c|c|c|}
\hline Variable & Group & $\begin{array}{c}\text { Confirmed } \\
\text { cases } \\
(n=63) \\
n(\%)\end{array}$ & $\begin{array}{c}\text { Suspected } \\
\text { cases } \\
(n=352) \\
n(\%)\end{array}$ & $\begin{array}{c}\text { Total } \\
(n=415) \\
n(\%)\end{array}$ & OR & $\begin{array}{l}95 \% \mathrm{Cl} \\
\text { LL-HL }\end{array}$ \\
\hline \multirow{2}{*}{ Age } & $\geq 65$ years & $13(20.6)$ & $47(13.4)$ & $60(14.5)$ & \multirow{2}{*}{1.68} & \multirow{2}{*}{$0.85-3.34$} \\
\hline & $<65$ years & $50(79.4)$ & $305(86.6)$ & $355(85.5)$ & & \\
\hline \multirow{2}{*}{ Sex } & Male & $35(55.6)$ & 179 (50.9) & $214(51.6)$ & \multirow{2}{*}{1.20} & \multirow{2}{*}{$0.70-2.07$} \\
\hline & Female & $28(44.4)$ & $173(49.1)$ & $201(48.4)$ & & \\
\hline \multirow{2}{*}{$\begin{array}{l}\text { Occupation at } \\
\text { time of diagnosis }\end{array}$} & Health worker & $11(17.5)$ & $36(10.2)$ & $47(11.3)$ & \multirow{2}{*}{1.85} & \multirow{2}{*}{$0.88-3.87$} \\
\hline & Other & $52(82.5)$ & $316(89.8)$ & $368(88.7)$ & & \\
\hline \multirow{2}{*}{$\begin{array}{l}\text { Pre-existing } \\
\text { comorbidities }\end{array}$} & Yes & $21(33.3)$ & $99(28.1)$ & $120(28.9)$ & \multirow{2}{*}{1.27} & \multirow{2}{*}{$0.72-2.26$} \\
\hline & No & $42(66.7)$ & 253 (71.9) & 295 (71.1) & & \\
\hline
\end{tabular}

Cl: confidence interval $\quad \mathrm{HL}$ : higher limit $\quad \mathrm{LL}$ : lower limit Source: COVID-19 Surveillance Database, IPK 2020
18,608 cases found age and sex profiles similar to those observed in China: a median age of 58 years (with an interquartile range of 43-74 years), $51 \%$ of whom were male.[16]

Given that both SARS-CoV-1 and MERS-CoV showed high intra-hospital transmission, health personnel involved in direct patient care were considered a high risk group.[17] In our study, medicine and nursing were the most common occupations among COVID-19-positive patients. By February 14,2020 , WHO had already reported 1716 confirmed cases among health workers in China (3.4\% of all cases) and 6 deaths.[18] On April 17, 2020, the Cuban Minister of Public Health reported that 92 health workers had tested positive for SARS-CoV-2; 47 (51\%) physicians and 30 (32.6\%) nurses (no deaths).[19] As health workers face the highest risk of infectious disease in the course of their professional duties, precautions must be taken at both the individual level (personal protective equipment, or PPE) and the institutional level to minimize risk of intra-hospital spread and to protect health workers and those around them.[20]

Persons with pre-existing comorbidities are at increased risk for developing severe forms of COVID-19. In this study, $44 \%$ of confirmed cases and $100 \%$ of deceased individuals had preexisting comorbidities, the most frequent being hypertension, asthma and diabetes mellitus. Yang found similar results in a systematic review of 8 studies involving 46,248 COVID-19 patients in Wuhan, China. Hypertension was the most common comorbidity (95\% Cl: $14-22)$, followed by diabetes mellitus (95\% $\mathrm{Cl}$ : 6-11), cardiovascular disease $(95 \% \mathrm{Cl}: 4-7)$ and respiratory disease (95\% Cl: 1-3).[21]

SARS-CoV-2 patients present a wide array of clinical symptoms, ranging from asymptomatic or oligosymptomatic to severe and sometimes fatal pneumonia.[22] In our study, 75\% of confirmed cases presented clinical manifestations at the time of admission, with cough and fever the most common, followed by sore throat, headache, asthenia and shortness of breath. The remaining $25 \%$ were asymptomatic. Yang's systematic review of COVID-19 patients in Wuhan, China, found similar results: the most common clinical manifestation was fever (95\% Cl: 21-40), followed by cough (95\% Cl: 59-76), fatigue (95\% Cl: 34-68) and dyspnea (95\% Cl: 21-40).[21] Another study, this one of patients admitted to the Wuhan University's Zhongnan Hospital between December 24, 2019 and February 24, 2020, found only $57.7 \%$ of patients were symptomatic, with the most common symptoms being fever, fatigue and a dry cough.[22]

Research involving the first 76 patients studied in Mexico in February 2020 found only 20\% of confirmed patients to be asymptomatic (the remainder had mild symptoms).[17] The Diamond Princess cruise ship, long quarantined in Japan, screened 3700 passengers, finding that $50 \%$ (96) of the 192 patients who tested positive were initially asymptomatic.[23] After 14 days of observation, most COVID-19-positive passengers developed symptoms, reducing the share of truly asymptomatic patients to $18 \%$ (95\% Cl: 15.5-20.2). These results differ from 
those published by China's Center for Disease Control of 72,314 cases, of which only $1.2 \%$ were asymptomatic.[24] Spain's Health Awareness Agency stresses the importance of accounting for asymptomatic COVID-19-positive individuals in designing and implementing infection prevention and control measures, given their impact on disease transmission. The Agency developed guidelines based on a systematic review of 24 studies.[25]

Cereda's study in Lombardy, Italy, found no statistically significant difference in viral loads taken from nasal swabs of asymptomatic and symptomatic patients, suggesting both groups had the same potential for transmitting the virus. However, contact tracing identified limited numbers of asymptomatic-infected patients, suggesting they may play a minor role in the overall spread of infection.[26] Additional research, including seroprevalence studies in the general population, will be necessary to accurately assess the role asymptomatic individuals play in SARS-CoV-2 transmission.

Epidemiologically, identifying and notifying suspected cases is an essential component of any disease surveillance system, as it demonstrates the transmissibility of infectious disease and can lead to a decrease in serious cases and deaths. In this study, $47 \%$ of suspected cases were admitted to health services more than 72 hours after symptom onset, despite media campaigns requesting that individuals seek out care in a timely manner and the existence of free universal health care. These findings are consistent with a retrospective study of 249 patients admitted to a hospital in Shanghai, 94.3\% (235) of whom experienced symptom onset an average of 4 days prior to hospitalization (range: $2-7$ days).[27]

The case fatality rate in this study $(7.9 \%)$ was higher than that reported later in the whole country during the beginning of the epidemic (2.6\%).[12] However, this was much lower than the rate recorded during a similar period in the largest study of hospitalized COVID-19 patients in the USA, which was roughly $25 \%$.[28] High case fatality rates may imply undetected transmission and an underestimation of the epidemic, indicating a need to improve epidemiological surveillance systems.[29] However, the underestimated value could be used to estimate the real number of infected individuals.[29]

In summary, this study showed the presence of disease in these first cases in Cuba was related to age $\geq 65$ years, male sex, occupation as a health worker engaged in direct patient care, and pre-existing comorbidities including hypertension, bronchial asthma and diabetes mellitus. This is in keeping with Wynant's systematic review, where significant correlates of infection included older age, male sex, pre-existing comorbidities, previous hospital admissions and negative social determinants of health.[30]

As this study includes only those patients admitted to IPK, the sample size is not very large, and the conclusions we can draw are limited. However, despite this and the fact that the study was limited to a single institution, the study's value lies in its examination of the first diagnosed cases of COVID-19 in Cuba, which can serve as a reference for the history of the disease in Cuba, the Caribbean and Latin America.

\section{CONCLUSIONS}

The first individuals diagnosed with COVID-19, who were admitted to Pedro Kourí Tropical Medicine Institute in Havana, Cuba, were mostly imported cases and adult men with pre-existing comorbidities that put them at higher risk of severe manifestations of the disease. These results contribute to knowledge of the history of the COVID-19 pandemic in Cuba and the region. -

\section{REFERENCES}

1. World Health Organization [Internet]. Geneva: World Health Organization; c2021. Discursos del Director General de la OMS. Alocución de apertura del Director General de la OMS en la rueda de prensa sobre la COVID-19 celebrada el 11 de marzo de 2020; 2020 Mar 11 [cited 2020 Jun 6]. Available at: https://www.who.int/es/dg/ speeches/detail/who-director-general-s-open ing-remarks-at-the-media-briefing-on-covid-19 ---11-march-2020. Spanish.

2. World Health Organization [Internet]. Geneva: World Health Organization; c2021. Emergencias sanitarias. Enfermedades. Nuevo coronavirus 2019. Orientaciones técnicas. Los nombres de la enfermedad por coronavirus (COVID-19) y del virus que la causa; [cited 2020 Jun 6]. Available at: https://www.who.int/es/emergencies/diseases/ novel-coronavirus-2019/technical-guidance/na ming-the-coronavirus-disease-(covid-2019)-and -the-virus-that-causes-it. Spanish.

3. Paules $\mathrm{Cl}$, Marston HD, Fauci AS. Coronavirus infections-More than just the common cold. JAMA [Internet]. 2020 Jan 23 [cited 2020 Feb 6];323(8):707-8. Available at: https://jamanet work.com/journals/jama/fullarticle/2759815

4. Centers for Disease Control and Prevention (CDC) [Internet]. Atlanta: Center for Disease Control and Prevention (CDC); c2021. Your Health. How COVID-19 spreads; [updated 2020 Oct 28; cited 2020 Mar 3]; [about 2 p.]. Available at: https://www.cdc.gov/coronavirus/about/index.html

5. Worldometer [Internet]. Shanghai: Dadax Limited; c2021. Available at: https://www.world ometers.info/coronavirus/\#page-top
6. Enfrentamiento a la COVID-19 en Cuba: Vigilancia activa desde la atención primaria de salud. Victoria [Internet]. 2020 [cited $2020 \mathrm{Apr}$ 6];Salud:[about 10 p.]. Available at: http://www .periodicovictoria.cu/enfrentamiento-a-la-covid -19-encuba- vigilancia-activa-desde-la-atencion -primaria-de-salud/. Spanish.

7. Gobierno Vasco. Protocolo de Vigilancia de Coronavirus SARS CoV 2 [Internet]. 2020 Oct 16 [cited 2020 Apr 6]. Available at: https://www .euskadi.eus/contenidos/informacion/vigilancia _protocolos/es_def/adjuntos/Protocolo-Coronavi rus-SARS-CoV-2-es.pdf. Spanish.

8. Cuba's COVID-19 strategy: main actions through April 23, 2020. MEDICC Rev [Internet]. 2020 Apr [cited 2020 Jun 6];22(2):50-2. Available at: https:// www.mediccreview.org/cubas-covid-19-strategy -main-actions-through-april-23-2020/

9. González García N, Chang Monteagudo A. RTPCR en tiempo real para el diagnóstico y seguimiento de la infección por el virus SARS-CoV-2. Rev Cubana Hematol Inmunol Hemoter [Internet]. 2020 [cited 2020 Aug 14];36. Available at: http://www.revhematologia.sld.cu/index.php/hih/ article/view/1262. Spanish.

10. Guanche-Garcell G. Covid-19. La necesidad de nuevos paradigmas de cooperación y riesgo de los trabajadores de la salud. Rev Habanera Cienc Méd [Internet]. 2020 [cited 2020 Aug 14];19 (Suppl):e_3456. Available at: http://www.revhabane ra.sld.cu/index.php/rhab/article/view/3456. Spanish.

11. Urquiza-Yero Y, Pérez-Ojeda MD, CortésGonzález AM, Escalona-Pérez I, Cabrales-León MO. Características clínico epidemiológicas de los pacientes de Las Tunas positivos al RT-PCR para la COVID-19. Rev Electrónica Dr. Zoilo E. Marinello Vidaurreta [Internet]. 2020 Jul-Aug [cited 2020 Aug 14];45(4). Available at: http:// revzoilomarinello.sld.cu/index.php/zmv/article/ view/2361. Spanish.

12. Carmona Tamayo E, Fariñas Acosta L. Cuba en Datos: A un mes de la COVID-19 en Cuba. Cubadebate [Internet]. 2020 Apr 10 [cited 2020 Jun 1];Especiales. Salud:[about 3 p.]. Available at: http://www.cubadebate.cu/espe ciales/2020/04/10/cuba-en-datos-a-un-mes-de -la-covid-19-en-cuba/\#.XtUeSEfB9LM. Spanish.

13. Li Q, Guan X, Wu P, Wang X, Zhou L, Trong Y, et al. Early transmission dynamics in Wuhan, China, of novel coronavirus-infected pneumonia. $\mathrm{N}$ Engl J Med. 2020 Mar 26;382(13):1199-1207. DOI: $10.1056 /$ NEJMoa2001316.

14. Sun K, Chen J, Viboud C. Early epidemiological analysis of the coronavirus disease 2019 outbreak based on crowd sourced data: a population-level observational study. Lancet Digital Health [Internet]. 2020 Apr 1 [cited 2020 Jun 1];2(4):e201-8. Available at: https://www thelancet.com/journals/landig/article/PIIS2589 $-7500(20) 30026-1 /$ fulltext

15. World Health Organization. Report of the WHO-China Joint Mission on Coronavirus Disease 2019 (COVID-19) [Internet]. Geneva: World Health Organization; 2020 Feb 16-24 [cited 2020 Jun 1]. 40 p. Available at: https:// www.who.int/docs/default-source/coronavi ruse/who-china-joint-mission-on-covid-19-final -report.pdf 
16. Gobierno de España [Internet]. Madrid: Gobierno de España; c2021. Ministerio de Sanidad. Enfermedad por nuevo Coronavirus, COVID-19. Situación actual; [cited 2020 Jun 1]. Available at: https://www.mscbs.gob.es/profesionales/salud Publica/ccayes/alertasActual/nCov/home.htm. Spanish.

17. Aragón-Nogales R, Vargas-Almanza I, MirandaNovales MG. COVID-19 por SARS-CoV-2: la nueva emergencia de salud. Rev Mex Pediatr [Internet]. 2019 Nov-Dec [cited 2020 Jun 1];86(6):213-8. Available at: http://www.scielo.org.mx/scielo.php ?pid=S0035-00522019000600213\&script=sci_art text. Spanish.

18. Pan American Health Organization; World Health Organization. Actualización Epidemiológica Nuevo coronavirus (COVID-19) [Internet]. Washington, D.C.: Pan American Health Organization; World Health Organization; 2020 Feb 14 [cited 2020 Apr 6]. 9 p. Available at: https://www.paho .org/sites/default/files/2020-02/2020-feb-14-phe -actualizacion-epi-covid19.pdf. Spanish.

19. En Cuba 92 profesionales de la Salud enfermos con la Covid-19. Radio Bayamo [Internet]. 2020 Apr 17 [cited 2020 Jun 1]. Available at: http:// www.radiobayamo.icrt.cu/2020/04/17/en-cuba -92-profesionales-de-la-salud-enfermos-con-la -covid-19/. Spanish.

20. Rosales QS, Cubas GS. El rol del médico en la transmisión nosocomial del SARSCoV-2. Rev Méd Costa Rica [Internet]. 2020 Jan-Jun [cited 2020 Jun 1];85(629). Available at: http://www .revistamedicacr.com. Spanish.

21. Yang J, Zheng Y, Gou X, Pu K, Chen Z, Guo Q, et al. Prevalence of comorbidities in the novel Wuhan coronavirus (COVID-19) infection: a systematic review and meta-analysis. Int J Infect Dis [Internet]. 2020 [cited 2020 Jun 1]. Available at: https://www .ncbi.nlm.nih.gov/pmc/articles/pmid/32173574/

22. Yang R, Gui X, Xiong Y. Clinical characteristics of patients with asymptomatic vs symptomatic Coronavirus disease 2019 in Wuhan, China. JAMA Netw Open [Internet]. 2020 May 27 [cited 2020 May 7];23(5):e2010182. DOI:10.1001/ja manetworkopen.2020.10182. Available at: https:// jamanetwork.com/journals/jamanetworkopen/full article/2766237

23. Mizumoto K, Kagaya K, Zarebski A, Chowell G. Estimating the asymptomatic proportion of coronavirus disease 2019 (COVID-19) cases on board the Diamond Princess cruise ship, Yokohama, Japan, 2020. Euro Surveill [Internet]. 2020 Mar 12 [cited 2020 May 7];25(10): 2000180. Available at: https://www.eurosurveil lance.org/content/10.2807/1560-7917.ES.2020 .25.10.2000180

24. The Novel Coronavirus Pneumonia Emergency Response Epidemiology Team. Vital surveillances: the epidemiological characteristics of an outbreak of 2019 novel Coronavirus dis- eases (COVID-19). China CDC Wkly [Internet] 2020 Feb [cited 2020 Jun 1]. Available at: http:// weekly.chinacdc.cn/en/article/id/e53946e2-c6c4 -41 e9-9a9b-fea8db1a8f51

25. Unidad de Asesoramiento Científico-técnico, Avalia-t, de la Agencia del Conocimiento en Salud (ACIS). Papel de las personas infectadas asintomáticas en la transmisión del coronavirus SARS-CoV-2 [Internet]. Santiago de Compostela: ACIS; 2020 Apr [cited 2020 Jun 3]. 16 p. Available at: https://coronavirus.sergas.gal/Contidos/ Documents/290/CompilacResumos_Asintomati cos.pdf. Spanish.

26. Cereda D, Tirani M, Rovida F, Demicheli V, Ajelli M, Poletti $P$, et al. The early phase of the COVID-19 outbreak in Lombardy, Italy. arXiv:2003.09320 [Preprint]. 2020 Mar 20 [cited 2020 Jun 3]: [30 p]. Available at: https://arxiv.org/ abs/2003.09320

27. Chen J, Qi T, Liu L, Ling Y, Qian Z, Li T, et al. Clinical progression of patients with COVID-19 in Shanghai, China. J Infect. 2020 May;80(5):e1-e6.

28. Davidson WK. Curso clínico y resultados en pacientes hospitalizados con COVID-19. Northwell, 1 de marzo-4 de abril, 2020 [Internet]. New York: The Feinstein Institutes for Medical Research 2020 [cited 2020 Jun 1]. Available at: http://www feinstein.northwell-edu. Spanish.

29. Medeiros de Figueiredo A, Daponte A, Moreira Marculino de Figuereido DC, Gil-García E, Kalache A. Letalidad del COVID-19: ausencia de patrón epidemiológico. Gac Sanit [Internet]. 2020 Apr 4 [cited 2020 Jun 1]. Available at: https://doi .org/10.1016/j.gaceta.2020.04.001. Spanish

30. Wynants L, Van Calster B, Bonten MMJ, Collins GS, Debray TP, Vos M De, et al. Systematic review and critical appraisal of prediction models for diagnosis and prognosis of COVID-19 infection. medRxiv [Preprint]. 2020 Apr 5 [cited 2020 Jun 1]: [39 p]. Available at: https://doi .org/10.1101/2020.03.24.20041020

\section{THE AUTHORS}

Niurka Molina-Águila (Corresponding author: niurka.molina@ipk.sld.cu), physician with dual specialties in family medicine and epidemiology, with a master's degree in infectious diseases. Assistant professor, Epidemiological Research and Surveillance Department, Diagnosis and Reference Research Center, Pedro Kourí Tropical Medicine Institute (IPK), Havana, Cuba. https://orcid.org/0000-0002-6267-4954

Elba Cruz-Rodríguez, physician with dual specialties in family medicine and epidemiology, with a master's degree in epidemiology. Associate professor and adjunct researcher,
Epidemiological Research and Surveillance Department, Diagnosis and Reference Research Center, IPK, Havana, Cuba. https:// orcid.org/0000-0002-9322-0875

Rita María Ferrán-Torres, physician with dual specialties in family medicine and epidemiology, with a master's degree in infectious diseases. Assistant professor, Epidemiological Research and Surveillance Department, Diagnosis and Reference Research Center, IPK, Havana, Cuba. https://orcid.org/0000-0003-0797-6797

Belkys María Galindo-Santana, physician with dual specialties in family medicine and epidemiology, with a master's degree in epidemiology and a doctorate in medical sciences. Senior professor and senior researcher, Epidemiological Research and Surveillance Department, Diagnosis and Reference Research Center, IPK, Havana, Cuba. https://orcid.org/0000-0002-8757-4036

Yanaris López-Almaguer, physician with dual specialties in family medicine and epidemiology, with a master's degree in public health. Associate professor and associate researcher, Ministry of Public Health (MINSAP), Havana, Cuba. https://orcid.org/0000-0003-2472-644X

Marcy Calderón-Martínez, physician with dual specialties in family medicine and epidemiology with a master's degree in public health. MINSAP Havana, Cuba. https://orcid.org/0000-0002-0030 $-2987$

Manuel Romero-Placeres, physician specializing in epidemiology with a doctorate in medical sciences. Director, full professor and senior researcher, IPK, Havana, Cuba. https://orcid .org/000-0001-9940-1581

Submitted: July 2, 2020

Approved for publication: March 11, 2021 Disclosures: None 